\title{
COMMISSIVE SPEECH ACT ON TIM COOK'S INTERVIEW IN OXFORD UNIVERSITY
}

\author{
Viola Rahmi Putri ${ }^{1)}$, Yola Merina $^{2)}$, Dona Alicia ${ }^{3)}$ \\ English Education Departmen, Stkip Pgri Sumbar, Indonesia \\ E-mail: ${ }^{1}$ violarahmi@gmail.com,${ }^{2}$ yolam3@gmail.com,${ }^{3}$ donaalicia11@gmail.com \\ Submitted: 24-08-2020 \\ Review: 15-04-2021 \\ Accepted: 19-04-2021 \\ DOI: https://doi.org/10.22202/tus.2020.v6i1.4290
}

\begin{abstract}
This research was conducted to know the kind of commissive and act the analysis of the three acts which are locution, illocution and perlocution could be found in the interview of Tim Cook in Oxford University. This research was a qualitative research. The source of data that used in this research was a video of an interview while the data which would be analyzed were utterances of the speakers in the interview. The research result was showed that there were two forms of commissive act that can be found in the interview which are promise and volunteering acts. From the result, it can be concluded that the use of promise act form was mostly act used during the interview of Tim Cook in Oxford University. This form was used by the interviewer when giving instruction during the interview or when asking question to Tim. Meanwhile the volunteering form was used when Tim volunteering himself to give an example to the audience of the interview.
\end{abstract}

Keywords: interview, speech act, tim cook

\section{INTRODUCTION}

Talking is one of many ways that people do to communicate. When people do talking they will utter words to others to express or explain what they want or what the feel. To express it people will speak so the other can understand and do acting as what information they get. When words have been said, people's brain will try to get the information and when the information has been obtained, people act like what the information that they have understood. This is usually called as speech act. Speech act is one of pragmatics study. It is developed by (J.L, 1962). Speech act is importance to be taught because it commonly used in daily conversation in any situation or context, such as formal and informal situations or conversations.

However, studying speaker utterance meaning trough a context is called pragmatic. pragmatics is concerned with the study of meaning communicated by 
speaker and interpreted by listener(Yule, 1996). It has consequently, more to do with the analysis of what people mean by their utterances than what the words or phrases in those utterances might mean by themselves.

While uttering something to other, people sometimes used some kind of speech acts. Speech act is classified into five categories which are; declarative, representative, expressive, commissive and directive (Searle in Cooren, 2015). First, Declarative is a kind of speech acts that makes the world fit the words, which means words change the worlds. In other words, speaker causes the situation change. Second, Representative speech acts is called assertive speech acts (Jarry in Oishi, 2006). They are all examples of the speakers representing the world as their believe it (Yule, 1996). Thus, statements of facts, assertions, conclusions, and descriptions are all examples of the speaker representing the world as he or she believes it is. Third, commissive is about what people going to do in the future. Commissive are those kind of speech acts that speaker use to commit themselves to some future action. Fourth, Expressive acts can be statements of pleasure, pain, like, dislike. This Last, Directive are those kind of speech acts that speaker use to get someone else to do something. It expresses what speaker wants, such as; command, orders, requests, and suggestions. It can be a positive or negative utterance. From all of five speech act forms, this study is focusing about commissive speech act. Commissives are those kinds of speech acts that can be used to commit what we have planned to do in future time. Some kinds of expressions of commissives like promises, threats, refusals, and pledges (Yule, 1996)

There are many forms of commissives, the general five are threat, promise, warning and refusal and guarantee. In addition, to make easier in differentiating those forms, there are several quite difference principles of the five forms of commissive utterance (Searle in Pambudi, Education, \& Faculty, 2017). Threat is an expression of an intention to inflict pain, injury, punishment or evil (Mifflin, 2003). It is a statement in which you tell someone that you will cause them harm or trouble if they do not do what you want. For example; come! Try! I must really scold you if you do not! 
Second, promise is an oral or written agreement to do or not to do something. Promise is an utterance used to remind the speaker about something to be done in the future. A commitment is also a promise. Promise is a declaration made, as to another person or themselves, with respect to the future, giving assurance that one will do or not to do something. It is a verbal commitment by one person to another agreeing to do. For example: I will take you to the movies tomorrow. There are five requirements to make a valid promise speech act (Searle, 1976). First, the speaker has to intend to do what he promises, then the speaker must believe (that the hearer believes) that the action is in the hearer's best interest. Next, the speaker has to believe that he can perform the action. The speaker must predicate a future action, and last the speaker has to predicate an act of him.

Third, warning is an utterance that intends others to be careful. It could be an advice, a warning, and a suggestion. For example: Don't even dare you take my flowers! I'll kill you. Fourth, when the speaker says firmly that the hearer will not do, give or accept something, it is called refusal. It is the act of refusing, denial of anything demanded, solicited, or offered for acceptance. For example: Unfortunately, I don't think I'll be able to attend the party. Refusal represents one type of dispreferred response or disagreement response. Refusal belongs to the form of commissive because they commit the refuser to performing an action. As a reactive speech act, a refusal functions as a response to an initiating act and is considered a speech act by which a speaker direct and indirect strategies. Thus, it has a function that the speaker rejects to do something. Lastly, volunteering is defined as offer to do something without being forced or paid to do it. It is to perform or offer to perform a service of someone's own free will. It means choosing to offer or give freely without being asked or obliged. Offer means saying that you are willing to do something for somebody or give something to somebody. Offer is the hearer's expression to offer an act for the hearer's or addressee's interest. 
Thus far,commissives are those kinds of speech acts that speaker uses to commit themselves to some future action. They express speaker's intention. They are promises, threats, refusals, and pledges, and they can be performed by the speaker alone or by the speaker as a member of a group. In using a commissives, the speaker undertakes to make the world fit the words (via the speaker) (Yule in Nabilah, 2013). When people perform commissives, they may say their speech by using the performative verbs such as promise, swear, guarantee, and vow.

However, In learning commissive speech act, the researcher has to understand about components of speech act. In performing speech acts, there are three components of speech acts. They are Locutionary, Illocutionary and Perlocutionary (Yule in Muhartoyo \& Kristani, 2013). Locutionary act is the basic act of utterance, or producing a meaningful linguistic expression. In other words, Locutionary can be defined as the act of making a meaningful utterance. Locutionary act is roughly equivalent to uttering a certain sentence with a certain meaning in the traditional sense (J.L, 1962). Thus, locutionary act is saying something with a certain meaning in traditional sense. In this case, it can be concluded in some points: the utterance of a sentence which determines sense and reference, also, the physical action to produce speech. The speaker usually uses the identifiable expression that is suitable with the context at that time. In other words, Locutionary is a meaningful and understandable utterance, for example; Watch out! There is a car.

Second, Illocutionary act is a complete speech act of doing something. Illucotionary act is such as informing, ordering, warning, and undertaking. The utterances have a certain (conventional) force. The illocutionary act is the minimal complete unit of human linguistic communication (Searle, 1976). Whenever someone talks to each other, they are performing illocutionary act. The points are: using a sentence to perform a function and the making of statement, an offer, a promise which means it is about the specific purpose of the speakers' intention in mind. Illocutionary acts, maintaining that here a person might find an "efficacy" of a statement and demonstrated its perfomative nature. The example of illocutionary is; do not run with scissors. By hearing the statement number 11 and 
understanding it as a warning, the auditor is warned, which is not to say that the auditor must or will act in any particular way regarding the warning. In conclusion, illocutionary acts has specific purposes of the speaker's intention in mind such as promising, asking, commanding, vowing, predicting, confirming.

Last, Percolutionary act is a speech act that produce and effect or Perlocutionary act is a reaction of the hearer the consequences of saying something. It is the effect of what the speaker said to the hearer. For example; The speaker says; I have much money. Then, the hearer says (as the effect of what speaker has stated); Treat me at the Korean restaurant to night. The effect or the respond of the hearer calls perlocutionary act. From the description above, it can be concluded that in speech act, the speaker at least produces three kinds of acts.

To support a research, it is important to have other researches that have been made by others researchers. The researcher is inspired to conduct a research after reading the research written by several previous researchers .The first one is a research which has done by Rumaira, 2015) that the research is aimed to find type of illocution and perlocution that was used by Mr. Keating in the movie and what good teacher reflection that showed through his speech act that he used. This research found that the movie conducted four types of speech act in the dialogue of the movie; they were representatives, directives, commissives, and declaratives. The most frequent speech acts performed by the teacher of the movie in the dialogue was directive. It was the type of speech act which the speaker's intention to make someone else to do something which means world fits word. The next research is a commissive form act research which the title is "The Speech Act of Threatening in English and Arabic with Reference to the Glorious Qur'an" by Kadhim and Abbas (2016). The result of the study proved that the speech act of threatening was expressed implicitly rather directly or explicitly in English. In both languages the speech act of threatening was often expressed implicitly rather than explicitly. Declarative forms were not the only forms that can express the act of threatening in both languages yet it could be expressed by other structures, such as imperative, interrogative and prohibitive. Last, the researcher also encounters the study that has been conducted by Pambudi (2017) with the title "An Analysis 
of Commissive speech act in The Vow". The research aimed at classifying the variations of form of commissive utterances, describing the equivalence of the implicature of commissive utterances, and describing the illocution and perlocution of the utterances that were used in the movie. In short, the researcher concludes that the understanding of speech act in people daily conversation, political conversations are more necessary. So people can interpret some conversations well.

In conclusion, to conduct a study a researcher has to know and find the purpose of what they will learn, the study should have the significant for the researchers themselves or for the reader who read it. So, in this study the researchers attempts to reach these following purposes, those are; wanting to know the forms of commissive speech act used in the Tim Cook interview in Oxford University in Oxford University and also the researcher wants to analyze of the three component of acts; locutionary, illocutionary and perlocutionary in commissive utterance forms that has been found in the interview, While the result of this research will be expected to give contributions for writer, reader, and other people who need the information on this research. Mainly, the significant of this study is to open up someone or reader's perception on inspiring someone to do or believing something through word.

\section{METHODS}

This research was a kind of qualitative research. Qualitative research method is a research procedure that produced descriptive data in form of words, written or spoken, of the person who can be observed (Moleong, 2010). In other words, this qualitative research provided the result of descriptive data in form of words rather than in form of numerical like quantitative research did. This source of the data was a video interview of Tim Cook in Oxford with its transcript of interview which contains utterances of the speakers that involved in the interview. In other word, the data of study were utterances. 
For the techniques of collection data, the researchers chose some techniques from Observation Method in collecting the data. Observational Method was a kind of method which observed the use of language in order to collect the data of it (Sudaryanto in Zaim, 2014) The reserachers chose some techniques from observation method which proposed by Sudaryanto, such as: non- participant observation technique, tapping technique and note taking. The based technique of the data collection was that non- participant observation technique. Nonparticipant observation technique was a step of collecting data when the researcher does not involve directly and play a role. In other words, the researcher would not involve in Tim Cook interview video conversation, but only as the person who watch the video of interview in order to collect the data for the research while the Tapping Technique and Note-taking were advance techniques that the researcher used during collecting data.

\section{FINDING AND DISCUSSION}

In the data analysis, the researchers firstly had agglomerated the utterances which have the same form of commisive speech act. Second the researcher gave each of datum codes based of the form, number datum, time and the speaker that spoke at that time. Third the researcher started analyzes and described the data with the context of the utterance support researcher's argumentation. After doing the analysis form the researchers came to next explanations about the component act they were; locutionary, illocutionary, and perlocutionary of utterance. The researcher would analyze each form completely. Finally, formsof commissive act that the researcher found in Tim Cook's interview were eight of promise (included a commitment in it), while one volunteering. In total there are nine data of two forms of commisive acts; commisive and volunteering.

\section{a. Promise}

Based on (Mifflin \& Houghton, 2003). Promise is an oral or written agreement to do or not to do something. Promise is an utterance used to remind the speaker about something to be done in the future. Beside, in commisive act, there is also a commitment. A commitment is 
kind a promise but it more intend. Oxford dictionary defines promise as a declaration of assurance that one would do something that particular thing happen. Beside oxford dictionary defines commitment as the state or quality of being dedicated to a cause, activity.

The explanations of those data were stated as follows;

\section{Datum 1: TCI/Interviewer/1/Promise/ 01'.11'”/}

When the interviewer opened the interview, he told some instruction what he was going to do, how the audiences should do when the interview was started. During giving instruction he told the audiences those words bellow which the researcher included it as one of commisive forms;

"Okay so just a few ground rules for a moment, Tim and I are gonna have a conversation for about the next 25 or so minutes"

Based on definition of commisive which was about the speaker's intention to do a future action so, this utterance was concluded. It is because when the interviewer giving the instruction using this utterance, he meant that he was informing the audiences about he was going to have talk with Tim Cook at first 20 or so minutes. It is a kind of promise based on the researcher analysis. Based on definition of promise which has been mention before, a promise is an oral or written agreement of a speaker to do something in the future (Mifflin, 2003). Besides, the reason of the researcher believed that is was a promise is because the interviewer was telling the correct information of what he has been said. It can be seen during the interview that he really took more than 20 minutes only talking with Tim.

The explanation of the three act of this utterance was like; the locution is the words "Okay so just a few ground rules for a moment, Tim and I are gonna have a conversation for about the next 25 or so minutes "which uttered by the interviewer. That utterance has meaning and the understanding of meaning from this utterance called as illocution. 
Illocution of this utterance is that the audiences understood that the interviewer would spend his first 20 minutes of interview by talking to Tim Cook. The perlocution was the interviewer did talking to Tim Cook and the audiences were listening to them.

\section{Datum 2: TCI/ Tim/ 1/commitment/ 02'.41'/}

When Tim cook was given time in retelling about his story in life,he mentioned about time when he had a commitment in life. Because this was a retelling the story so he mentioned it in form of past tense. But, from what the researcher thought and understood about a commitment and also a commisive, the researcher concluded it as a commitment and forms a comissive. This was the utterance;

"You know at in 1982 I was about 21 years old and coming out of undergraduate school, ...I wanted to find a job that I loved and I wanted to love the work that I did."

Based on the data above, the researcher chooses it into a commitment more rather than a promise. Oxford dictionary defines commitment as the state or quality of being dedicated to a cause, activity. Although a commitment is a part of promise but, it could be seen how Tim intended? it in his life as he told the story of his life during the interview. He has mentioned that the reason why he had this commitment to his life is because he did not want to work like his father who did not love his work. He also proved his commitment by quitting previous job and then work with Steve Job in Apple while many people told him to not do that. But, he kept followed his intuition and worked with Steve until he became a CEO just like today. In this situation, he was trying to show the audiences how his commitment toward his job caused something bigger in his life.

The three acts analysis of Tim's statement was like; Tim said to himself "I want to find a job that I love and I want to love the work that I did". Illocution of his statement would be like; Tim keeps in his heart the words. The Perlocution is that finally he really found the job that he love, 
and he really committed his words to get a job that he love and he love his work.

\section{b. Volunteering}

Volunteering is defined as offer to do something without being forced or paid to do it. It is to perform or offer to perform a service of someone's own free will. The American Red Cross, 1989 defines that "Volunteers were individuals who reach out beyond the confines of their paid employment and of their normal responsibilities to contribute time and service to a non-for-profit cause in the belief that their activity is beneficial to other as well as satisfying to themselves". It means choosing to offer or give freely without being asked or obliged. Offer means saying that you were willing to do something for somebody or give something to somebody.

In this research, the researcher only found 1 data about volunteering. The explanations of this data as follows;

\section{Datum 3: TCI/ Tim/ 1/volunteering/ 34'.12"'/}

When Tim was given a question from a student about how to step on failure he was answer the question along with the example. On making the audiences understood the situation of his failure that he had ever passed in life, he volunteering giving an example. Here was the utterance that Tim cook said at that time;

"... You have to recognize when something that you're working on is pushing on a wall and let me give you an example that was actually pretty big at Apple at the time"

Volunteering is defined as offer to do something without being forced or paid to do it. It is to perform or offer to perform a service of someone's own free would. From the statement above Tim volunteering gives the audiences an example about how was the failure that he has ever passed in his company. The words of pretty big here did not mention about how pretty someone face it. Yet, it described how influential the problem he get at that time. 
The three act of this data is that; perlocution; Tim says "let me give you an example that was actually pretty big at Apple at the time". The perlocutionis that the audiences understood that Tim is going to give them an example. The perlocution is that Tim gave them the example and the audiences were listened to the example. They might take the example as lesson.

After analyizing the data, the researcher found out that the data were dominated by promise and commitment form. Definition of a commitment is kind a promise but it more intend. Oxford dictionary defines commitment as the state or quality of being dedicated to a cause or activity. During watching and listening to the interview of Tim Cook, the researcher has understood that Tim in this interview, firstly during 25 minutes earlier, told much about his carrier and his commitment is life. Beside the form of promise mostly uttered by the interviewer in guiding and telling the audience what he would do next in the interview. This was why the researcher thought promise and commitment form can be dominated the form of commisive in this interview.

In the opposite, volunteering is the lower result of commisive form that the researcher found in the interview. It is because during the interview, volunteering only appeared when Tim was answering the question form one of the student to give them example about failure. Tim offered to tell them the example that Apple had ever faced so the student could understand and accepted his argument clearly.

Afterward, about three component act; locutionary, illocutionary and perlocutionary mostly appeared generally during the interview, such as; locutionary would be found right when the speaker in the interview just uttered the words. The illocutionary would be the hearer's understanding of the words that uttered by the speaker. Last, the perlocutionary will be showed as the effect that the speaker did. It could be like the interviewer asked Tim question, the interviewer keeping the audience hands up just like he promised.

After finding the commisive form the researcher could make a conclusion there are the different finding of this study with other researcher study. It can be seen that, in interview, speakers were not scripted to utter something. In 
interview someone might tell the audience something unexpectedly. In this study also included a form of a commitment that had been made in the past that had effect in someone future life as Tim Cook did in this interview.

\section{CONCLUSION}

In this research, the researchers concluded that commissive act was one of the language studies that could be found in daily conversation. It was also known as a communication along with an act which make us to seek much information while having communication. It made communication could be more understood and the hearer could find what the speaker really meant without being misunderstanding. Through this research, the researcher hoped that this research would be useful for those who read it. This research contained information about commisive act which was important in communication. The researcher expected that the reader would understand what they just said or what they just heard in a communication. Thus, they could build a meaningful conversation. Beside, by reading this research, the researcher suggested the next researcher to study more about commisive since this study is not a perfect study yet. The researcher also suggested to other researchers who wanted to study about speech to be more develop research about other subs of speech act such as declarative act, representative act, expressive, or directive act, so the study about language use could be more effloresce.

\section{REFERENCES}

American Red Cross. (1989). Taking Volunteerism into the first the first 21rst Century. The Journal of Volunteer Administration, III, 1.

Cooren, F. (2015). Speech Act Theory A Critical Overview. The International Encyclopedia OfLanguage and Social Interaction. https://doi.org/10.1002/9781118611463/wbielsi055

J.L, A. (1962). How to do things with words (oxford, Ed.). Oxford University Press.

Mifflin, \& Houghton. (n.d.). Dictionary of English Language. Retrieved from http://www.thefreedictionary.com/promise

Moleong Lexy, J. (2010). Metode Penelitian Kualitatif. Bandung: PT. Remaja Rosdakarya. 
Muhartoyo, M., \& Kristani, K. (2013). Directive Speech Act in The Movie "Sleeping Beauty." Humaniora, 4(2), 949. https://doi.org/10.21512/humaniora.v4i2.3536

Oishi, E. (2006). Austin's Speech Act Theory and the Speech Situation. Esercizi Filosofici, 1-14. Retrieved from http://www2.units.it/eserfilo/art106/oishi106.pdf

Pambudi, N. U. R. W., Education, I., \& Faculty, T. T. (2017). an Analysis of Commissive Speech Act Used in the Vow.

Rumaira, C. (2015). an Analysis of Speech Acts in the Dead Poets Society. Yogyakarta, 1-275.

Searle, J. R. (1976). Speech Act. An Analysis in Philosophy of Language (C. U. Press, Ed.). Cambridge.

Yule, G. (1996). Pragmatic (Oxford, Ed.). Oxford University Press.

Zaim, M. (2014). Metode Penelitian Bahasa: Pendekatan Struktural 12 Metode Penelitian Bahasa: Pendekatan Struktural.

\section{BIOGRAPHY}

Viola Rahmi Putri is an undergraduate student of English Education Program College of Teacher Training and Education (STKIP) PGRI Sumbar, Indonesia, year; 2019. She writes the paper for her final comprehension test to finish her study in the college. 